\title{
PROFIL PEMANFAATAN HASIL-HASIL PENELITIAN DOSEN UNIVERSITAS NEGERI YOGYAKARTA
}

\author{
Suharjana, Tri Hartiti Retnowati, Suharti dan Sri Atun \\ Universitas Negeri Yogyakarta \\ email: suharjana_fikuny@yahoo.com
}

\begin{abstract}
Abstrak: Profil Pemanfaatan Hasil-Hasil Penelitian Dosen Universitas Negeri Yogyakarta. Tujuan penelitian ini adalah untuk mengetahui profil penelitian, pemanfaatan hasil-hasil penelitian, upaya yang perlu dilakukan LPPM dalam meningkatkan kualitas dan kuantitas penelitian, luaran/pemanfaatan hasil-hasil penelitian. Populasi penelitian adalah dosen-dosen yang melaksanakan kegiatan penelitian selama kurun waktu 2007-2011. Sampel penelitian diambil secara purposif sampling. Metode pengumpulan data menggunakan teknik dokumentasi, wawancara, dan angket. Analisa data menggunakan teknik diskriptif. Kesimpulan penelitian ini dapat diketahui jumlah penelitian sebanyak 859 judul. Sumber dana penelitian tersebut berasal dari DP2M dengan skim penelitian Hibah Bersaing, fundamental, Rapid, Stranas, dan DIPA UNY. Profil pemanfaatan hasil penelitian dosen berupa artikel yang diterbitkan dalam jurnal nasional yang belum terakreditasi sebanyak 35 judul, sebagai pemakalah dalam seminar nasional sebanyak 75 judul, seminar internasional sebanyak 21 judul, teknologi tepat guna sebanyak 24 judul, dan buku ajar sebanyak 21 judul. Upaya yang perlu dilakukan LPPM dalam meningkatkan kualitas dan kuantitas penelitian, reviewer penelitian sesuai bidang ilmu; berkompeten, seminar instrumen dan hasil perlu ditingkatkan kualitasnya, peluang penelitian perlu diperbanyak, serta tawaran penelitian tidak hanya melalui website. Upaya yang perlu dilakukan LPPM dalam meningkatkan kualitas luaran/ pemanfaatan hasil-hasil penelitian adalah mengadakan workshop penulisan artikel nasional terakreditasi/internasional, mendorong terbitnya jurnal yang terakreditasi, dan memfasilitasi bantuan pengurusan pendaftaran HKI.
\end{abstract}

Kata kunci: Profil pemanfaatan hasil penelitian

\begin{abstract}
The Profile of Utilization of The The Lectures' Research Results at Yogyakarta State University. The purpose of this study was to determine the profile of the study, the utilization of research results, efforts need to be done by 'LPPM', in improving the quality and quantity of research, outcomes/utilization of research results. The populations of this study are professors conducting research during the period 2007-2011. Samples were taken by purposive sampling. Methods of data collection use the techniques of documentation, interviews, and questionnaires. The data are analyzed by using descriptive techniques. From the conclusions of this of research can be seen that the number of of research as many as 859 titles. Sources of research funding comes from DP2M, using the research competitive grants scheme, fundamentals, Rapid, Stranas, and DIPA UNY. Profile faculty utilization of research results, in the form of published articles in a national journal that has not been accredited with a total of 35 titles, as national seminar speakers with a total of 75 titles, international seminars with a total of 21 titles, appropriate technology as many as 24 titles, and books of learning as many as 21 titles. Effort that need to be made by LPPM in improving the quality and quantity the research, the reviewer in accordance with science the research; qualified, seminars instruments and the results need to be improved, research opportunities need to be multiplied, and the offer of the research is not only through the website. Effort that need to be made by LPPM in improving the quality of outcomes/utilization of research results is by holding, "the article
\end{abstract}


writing workshops nationally accredited/international", encouraging the publication of accredited journals, and facilitating the process of registration of IPRs.

Keyword: The Profile of the Utilization of research result

\section{PENDAHULUAN}

Sebagai bagian dari Lembaga Pendidik Tenaga Kependidikan (LPTK), Universitas Negeri Yogyakarta semakin memantapkan dirinya untuk menjadi universitas kependidikan kelas dunia (world class university) yang berlandaskan ketaqwaan, kemandirian dan kecendekiaan. Hal ini selaras dengan rumusan tujuan pendidikan nasional yang tertuang dalam Undang-undang Nomor 20 Tahun 2003 tentang Sistem Pendidikan Nasional yang menyatakan bahwa tujuan pendidikan nasional adalah berkembangnya potensi peserta didik agar menjadi manusia yang beriman dan bertakwa kepada Tuhan Yang Maha Esa, berakhlak mulia, sehat, berilmu, cakap, kreatif, mandiri, serta menjadi warga negara yang demokratis dan bertanggung jawab. Berbagai upaya perbaikan terus dilakukan guna mewujudkan visi UNY tersebut.

Penelitian sebagai salah satu pilar tridharma selain pendidikan dan pengabdian masyarakat, memiliki peran sentral dalam upaya mewujudkan visi UNY. Secara tegas dikemukakan bahwa salah satu fungsi UNY adalah menyelenggarakan dan mengembangkan penelitian dalam rangka pengembangan ilmu pengetahuan, teknologi, seni, dan olahraga. Dengan demikian, kegiatan penelitian perlu diselenggarakan untuk menemukan, mengembangkan, dan menyebarluaskan ilmu pengetahuan, teknologi, seni, dan/atau olahraga, yang menyejahterakan individu dan masyarakat, mendukung pembangunan daerah dan nasional, serta berkontribusi pada pemecahan masalah global.

Aktivitas penelitian dosen dengan dana DIPA DP2M selama rentang tiga tahun terakhir menunjukkan adanya fluktuasi. Pada periode 2008, 246 judul penelitian didanai dari 9 sumber dana dan melibatkan 44,95\% dosen UNY. Jumlah ini meningkat di perio- de 2009, dengan jumlah usulan penelitian yang didanai sebanyak 248 dan melibatkan $52,34 \%$ dosen UNY dari 10 sumber dana penelitian. Pada periode 2010 terdapat 385 judul penelitian yang didanai dari 6 sumber. Ditinjau dari dana yang terserap pada tahun 2008 adalah Rp. 2.602.842.000,-. Sedangkan pada tahun 2009 dan 2010 berturutturut sebanyak Rp. 3.114.380.000,- dan Rp. 4.919.700.000,-. (RIP UNY, 2012).

Kegiatan penelitian yang dilakukan di 12 pusat studi pada rentang waktu tiga tahun terakhir dari segi jumlah kegiatan mengalami peningkatan dari tahun 20082010. Jika diukur dari jumlah serapan dana (kontrak kegiatan), tahun 2009 merupakan periode pelaksanaan kegiatan yang menyerap dana paling besar, yaitu sejumlah Rp. 1.150.000.000,-. Sedangkan tahun 2008 merupakan periode pelaksanaan kegiatan dengan serapan dana terkecil, yaitu sebesar Rp. 261.000.000,-. Total kegiatan yang telah dilaksanakan oleh 12 pusat studi selama rentang tiga tahun terakhir sebanyak 102 kegiatan, dan dengan serapan dana sebesar Rp. 1.951.000.000,-. (RIP UNY, 2012).

Ditinjau dari jumlah dana yang terserap dan jumlah kegiatan penelitian, sebanyak lebih dari 500 judul kegiatan dalam waktu tiga tahun terakhir yang telah dilakukan oleh para dosen UNY tersebut, mestinya sudah banyak hasil-hasil penelitian yang diperoleh selama kurun waktu tersebut. Namun demikian dari data yang ada di LPPM, selama rentang dua tahun 2008-2009 publikasi ilmiah yang baru dilaporkan sebanyak 7 publikasi ilmiah tingkat internasional dan 87 tingkat nasional terakreditasi. Sedangkan yang lainnya masih berupa artikel yang disampaikan dalam forum pertemuan ilmiah di tingkat nasional maupun internasional. Luaran dalam bentuk Hak atas Kekayaan Intelektual (HKI), kategori hak cipta, desain produk industri dan perlindungan varietas 
tanaman juga telah dihasilkan meski jumlahnya masih sangat terbatas, dalam kurun tiga tahun hanya ada 8 judul yang didaftarkan hak patennya. Dengan demikian masih banyak hasil penelitian dosen yang belum dilaporkan pemanfaatannya. Untuk mengoptimalkan pemanfaatan hasil-hasil penelitian yang telah dilakukan oleh dosen UNY perlu dilakukan identifikasi profil pemanfaatan hasil penelitian yang telah dilakukan dosen selama kurun waktu tertentu (2007-2011). Berdasarkan latar belakang tersebut, maka ruumusan masalahnya adalah sebagai berikut: 1) Bagaimanakah profil penelitian yang dilakukan dosen dalam kurun waktu 20072011? 2) Bagaimanakah profil pemanfaatan hasil-hasil penelitian yang diperoleh oleh dosen UNY selama kurun waktu 2007-2011? 3) Bagaimanakah upaya yang perlu dilakukan LPPM dalam meningkatkan kualitas dan kuantitas penelitian? 4) Bagaimanakah upaya yang perlu dilakukan LPPM dalam meningkatkan kualitas luaran/ pemanfaatan hasil-hasil penelitian?

Kegiatan dan proses belajar mengajar di UNY didukung oleh 1.047 orang tenaga akademik dengan kualifikasi jenjang pendidikan sebagai berikut: SI sebanyak 139 orang $(17,06 \%)$, S2 sebanyak 740 orang $(70,54 \%)$, dan S3sebanyak 130 orang (12,39\%). Dari sisi jenis kelamin, 657orang $(62,63 \%)$ pria dan 392 orang $(37,37 \%)$ wanita. Berdasarkan komposisi tersebut dapat pula dinyatakan bahwa sebanyak 82,93\% dosen bergelar S2 ke atas. Komposisi ini terus bergeser sehingga dosen bergelar S1 makin sedikit. Jumlah dosen dengan jabatan fungsional guru besar mencapai 48 orang $(4,58 \%)$ (www.uny.ac.id).

Aktivitas penelitian dosen dengan dana DIPA DP2M selama rentang tiga tahun terakhir menunjukkan adanya fluktuasi. Pada tahun 2008, sebanyak 56\% dari total usulan penelitian yang diajukan oleh dosen-dosen UNY didanai pada sebaran 13 skim penelitian nasional, dan dosen yang terlibat sebanyak $19,71 \%$ dari seluruh dosen UNY. Namun prestasi ini mengalami penurunan hampir separuh pada periode 2009, di mana hanya 29\% judul proposal penelitian yang didanai dengan keterlibatan $16,56 \%$ dosen. Pada periode 2010, meski mengalami peningkatan dibanding tahun 2009, namun peningkatan ini tidak signifikan di mana hanya $30 \%$ judul usulan penelitian yang didanai dan $18,67 \%$ dosen yang terlibat dalam kegiatan penelitian tersebut.

Kegiatan penelitian yang dilakukan di 12 pusat studi pada rentang waktu tiga tahun terakhir dari segi jumlah kegiatan mengalami peningkatan dari tahun 20082010. Jika diukur dari jumlah serapan dana (kontrak kegiatan), tahun 2009 merupakan periode pelaksanaan kegiatan yang menyerap dana paling besar, yaitu sejumlah Rp. 1.150.000.000,-. Sedangkan tahun 2008 merupakan periode pelaksanaan kegiatan dengan serapan dana terkecil, yaitu sebesar Rp. 261.000.000,-. Total kegiatan yang telah dilaksanakan oleh 12 pusat studi selama rentang tiga tahun terakhir sebanyak 102 kegiatan, dan dengan serapan dana sebesar Rp. 1.951.000.000,-. Kegiatan penelitian yang dilaksanakan seluruh pusat studi selama rentang tiga tahun terakhir mengalami peningkatan yang pesat. Pada tahun 2008, terdapat 23 judul penelitian yang telah dilaksanakan oleh 12 pusat studi. Jumlah ini mengalami kenaikan menjadi 31 pada tahun 2009, dan jauh lebih banyak lagi pada periode tahun 2010, yaitu sebanyak 48 judul.

Indikator kinerja utama penelitian (IKUP) ditentukan oleh luaran atau pemanfatan hasilhasil penelitian. Terdapat sembilan jenis luaran penelitian yang selama ini menjadi pijakan aktivitas penelitian dosen, yaitu publikasi ilmiah, sebagai pemakalah dalam pertemuan ilmiah sebagai pemakalah utama (Keynote speaker), HAKI, teknologi tepat guna, desain model, dan buku ajar. Dari data yang ada di LPPM UNY tahun 2011 (RIP UNY, 2011), publikasi ilmiah selama rentang dua tahun 2008-2009 terdapat 7 publikasi ilmiah tingkat internasional dan 87 tingkat nasional terakreditasi, publikasi tingkat lokal sebanyak 183 buah. Selain itu, luaran sebagai pemakalah dalam forum pertemuan ilmiah merupakan luaran kedua yang paling 
banyak dihasilkan. Untuk jenis Hak atas Kekayaan Intelektual (HKI), hanya ada 8 judul HAKI yang didaftarkan, sedangkan laporan penelitian yang belum dipublikasikan sebanyak 648 buah.

Melihat begitu banyaknya laporan yang belum dipublikasikan menarik untuk dikaji lebih dalam, benarkah para peneliti belum mempublikasikan hasil karyanya atau masih sedikitnya informasi pemanfaatan hasil penelitian yang ada di LPPM UNY. Oleh karena itu penelitian untuk mendapatkan data tentang profil pemanfaatan hasil-hasil penelitian sangat diperlukan. Dari data tersebut dapat digunakan sebagai masukan dalam merancang program penelitian yang lebih berkualitas, maupun kegiatan untuk memanfaatkan hasil-hasil penelitian dosen. Oleh karena keberhasilan program penelitian dalam suatu lembaga dapat dilihat dari banyaknya luaran hasil penelitian, baik berupa artikel yang dipublikasikan secara nasional maupun internasional, jumlah HAKI, teknologi tepat guna yang diaplikasikan ke masyarakat, maupun buku ajar. Luaran hasil penelitian tersebut mempunyai peranan penting dalam meningkatkan kualitas perguruan tinggi. Dari data ranking webometrik tahun 2011 UNY menduduki peringkat 19 perguruan tinggi di Indonesia, 63 tingkat Asia, dan 1831 tingkat dunia.

Suatu survai oleh Scientific American di tahun 1994 menunjukkan bahwa kontribusi ilmuwan Indonesia pada khasanah pengembangan dunia ilmu setiap tahunnya hanyalah sekitar $0.012 \%$, yang jauh berada di bawah Singapura yang berjumlah $0.179 \%$, apalagi kalau dibandingkan dengan USA yang besarnya lebih dari $25 \%$. Oleh beberapa pengamat barat, jerih payah upaya ilmuwan Indonesia untuk ikut berkontribusi terhadap perkembangan khasanah ilmiah dunia diistilahkan lost science in the third world. Pernyataan bernada sumbang ini terutama disebabkan karena hasil yang disumbangkan mereka tidak sampai ke hadapan mitra bestari sesama ilmuwannya yang sebidang hanya karena ditulis dalam berkala yang berjangkauan terbatas (DIKTI, 2012).

\section{METODE}

Desain penelitian ini adalah diskriptif atau eksploratif, untuk menggali data sesuai apa adanya. Penelitian ini menggunakan populasi dosen peneliti UNY periode tahun 2007-2011 yang tercantun dalam sipenonline LPPM UNY tahun 2012. Sampel penelitian diambil secara purposif berdasarkan pertimbangan dana penelitian dibatasi yang di danai lebih dari Rp. 20.000.000 (dua puluh juta rupiah). Oleh karena penelitian dengan dana tersebut diharapkan dapat menghasilkan luaran seperti publikasi, paten, bahan ajar, maupun yang lainnya.

Metode pengambilan data dilakukan dengan metode dokumentasi, wawancara, maupun pengiriman angket ke dosen yang melakukan penelitian periode tahun 20072011. Instrumen yang digunakan dalam penelitian ini adalah berupa angket untuk menjaring semua informasi tentang pemanfaatan hasil-hasil penelitian yang telah dilakukan. Untuk mendapatkan informasi tersebut akan dibuat angket yang berisi: identitas peneliti, judul Penelitian, Skim penelitian, Jumlah dana, Luaran Penelitian, yang meliputi : publikasi ilmiah, sebagai pemakalah dalam pertemuan ilmiah sebagai pemakalah utama (Keynote speaker), HAKI, teknologi tepat guna, desain model, dan buku ajar. Kesulitan yang dihadapi dosen dalam publikasi khususnya, maupun dalam pemanfaatan hasil penelitian pada umumnya. Saran peneliti untuk meningkatkan kualitas LPPM. Teknik analisis data yang digunakan dalam penelitian ini adalah dengan analisis diskriptif.

\section{HASIL DAN PEMBAHASAN}

Data penelitian yang telah dilakukan oleh dosen UNY yang terdapat dalam sipenonline LPPM UNY tahun 2012 sebanyak 859 judul dengan rincian berasal dari fakultas: FBS: 150 judul; FE : 94 judul; FIK: 151 judul; FIP: 173 judul; FISE: 127 judul; FMIPA: 164 judul. Sumber dana penelitian tersebut berasal dari DP2M dengan skim penelitian Hibah Bersaing, fundamental, Rapid, Stranas, DIPA UNY baik unggulan universitas maupun DIPA 
Tabel 1. Data pemanfaatan hasil penelitian dosen

\begin{tabular}{|c|c|c|c|c|}
\hline No. & Jenis Luaran & & Jumlah & $\begin{array}{l}\text { Prosentase } \\
\quad(\%)\end{array}$ \\
\hline \multirow{3}{*}{1} & \multirow{3}{*}{ Publikasi IImiah dalam jurnal } & Internasional & 6 & 0,06 \\
\hline & & Nasional Terakreditasi & 16 & 0,15 \\
\hline & & Nasional Belum Terakreditasi & 35 & 0,33 \\
\hline \multirow{3}{*}{2} & \multirow{3}{*}{ Sebagai pemakalah dalam pertemuan ilmiah } & Internasional & 22 & 0,21 \\
\hline & & Nasional & 74 & 0,70 \\
\hline & & Lokal & 18 & 0,17 \\
\hline \multirow{3}{*}{3} & \multirow{3}{*}{$\begin{array}{l}\text { Sebagai pembicara utama (Keynot Speaker) } \\
\text { dalam pertemuan ilmiah }\end{array}$} & Internasional & 2 & 0,02 \\
\hline & & Nasional & - & - \\
\hline & & Lokal & 4 & 0,04 \\
\hline 4 & Visiting Professor & Internasional & - & - \\
\hline \multirow{3}{*}{5} & \multirow{3}{*}{ Hak Atas Kekayaan Intelektual (HKI) } & Paten & 4 & 0,04 \\
\hline & & Paten Sederhana & 1 & 0,01 \\
\hline & & Hak Cipta & 1 & 0,01 \\
\hline 6 & Teknologi Tepat Guna & & 24 & 0,23 \\
\hline 7 & $\begin{array}{l}\text { Model/Prototype/Desain/ } \\
\text { Karya seni/Rekayasa/Sosial }\end{array}$ & & 15 & 0,14 \\
\hline 8 & Buku Ajar & & 21 & 0,20 \\
\hline 9 & Laporan penelitian yang tidak dipublikasikan & & 107 & 100 \\
\hline
\end{tabular}

masing-masing fakultas. Sampel penelitian dibatasi berdasarkan anggaran penelitian yang di danai lebih dari Rp. 20.000.000 (Tiga puluh juta rupiah) sebanyak 213 judul.

Selanjutnya dikirimkan angket kepada para peneliti tersebut, dan diberi waktu selama kurang lebih 1 bulan (15 Mei - 15 Juni 2012). Selanjutnya sampai batas waktu yang ditentukan dapat terkumpul 107 angket yang diisi oleh para responden. Analisis terhadap angket tersebut diperoleh data seperti pada Tabel 1 .

Pertanyaan yang sifatnya terbuka yang diajukan mengenai kesulitan dalam publikasi, pendaftaran paten, maupun pemanfaatan hasil penelitian yang lainnya, sebanyak 40 responden menyatakan mengalami kesulitan, 34 responden menyatakan tidak, dan sebanyak 33 responden tidak menjawab. Alasan yang dikemukakan meliputi hal-hal sebagai berikut:
1. Tidak ada waktu untuk mengurus paten/ haki

2. Tidak tau cara membuat deskripsi paten

3. Kurang yakin hasil penelitian dapat dipatenkan

4. Terbatasnya jurnal bidang pendidikan/ bidang ilmu yang terakreditasi

5. Jurnal terakreditasi lama terbitnya

6. Mekanisme artikel yang akan diterbitkan di CP (Cakrawala Pendidikan) kurang transparan

7. Kesulitan publikasi di jurnal internasional

Saran dan masukan dari para responden untuk LPPM dalam meningkatkan kualitas dan kuantitas penelitian adalah masukan tentang reviewer penelitian yang sesuai bidang ilmu dan sudah berkompeten sebayak 5 responden, peningkatan kualitas seminar instrumen/ hasil penelitian dinyatakan oleh 
4 responden, serta peluang penelitian atau dana penelitian diperbanyak sebanyak 3 responden.

Selanjutnya saran/masukan untuk LPPM dalam peningkatan kualitas pemanfaatan hasil penelitian dosen, maupun kualitas penelitian dosen secara umum yang dinyatakan oleh para responden adalah masukan dari para responden untuk lembaga paling banyak adalah agar LPPM mengadakan workshop penulisan artikel nasional terakreditasi/ internasional sebanyak 19 responden, mendorong terbitnya jurnal yang terakreditasi sebanyak 11 responden, dan memfasilitasi bantuan pengurusan pendaftaran HAKI sebanyak 7 responden.

Dari hasil penelitian ini dapat diketahui bahwa hasil-hasil penelitian Dosen UNY periode 2007-2011 belum dimanfaatkan secara optimal. Oleh karena apabila ditinjau dari jumlah penelitian yang berhasil diraih cukup banyak, namun jika dilihat dari luaran yang diperoleh berupa artikel yang diterbitkan dalam jurnal nasional terakreditasi maupun jurnal internasional masih sangat kurang, demikian juga jika dilihat dari jumlah HAKI yang diperoleh. Selanjutnya apabila ditinjau dari alasan yang dikemukakan oleh para responden yaitu terbatasnya jurnal bidang pendidikan/ bidang ilmu yang terakreditasi, jurnal terakreditasi lama terbitnya, serta kesulitan publikasi di jurnal internasional perlu segera dicari jalan keluarnya, misalnya dengan menyelenggarakan workshop secara rutin, maupun mendorong penerbitan jurnal nasional yang terakreditasi, terutama jurnaljurnal yang ada di LPPM.

Hasil penelitian menunjukkan bahwa sebagian besar dosen kesulitan dalam usaha memanfaatkan hasil penelitian dalam bentuk publikasi ilmiah atau hak paten. Secara nyata baru sekitar 20\% hasil penelitian dapat dimanfaatkan peneliti terutama dalam bentuk publikasi dalam jurnal ilmiah atau dipresentasikan dalam seminar nasional. Rendahnya pemanfaatan hasil penelitian ini disebabkan oleh banyak faktor. Untuk membuat karya yang berupa tulisan di sebuah jurnal ilmiah diperlukan kemampuan merubah dari for- mat laporan menjadi format karya ilmiah. Dalam sebuah jurnal ilmiah biasanya ada ketetuan-ketentuan yang digunakan sebagai panduan penulisan. Majalah ilmiah akan memuat tulisan dalam bidang ilmu tertentu, sehingga hanya penelitian-penelitian yang serumpun yang bisa dipertimbangkan untuk dimuat dalam majalah ilmiah tersebut. Kedalaman materi dan ketepatan dalam memilih metode penelitian akan menjadi pertimbangan penting dalam memutuskan bisa dimuat atau tidak dalam sebuah jurnal ilmiah. Salah satu contoh jurnal ilmiah di UNY yang pada saat ini statusnya terakreditasi adalah "Cakrawala Pendidikan" atau CP. Jurnal ini sangat diburu oleh para penulis di seluruh Indonesia terutama para dosen yang akan mengusulkan ke Guru Besar. Hasil penelitian ada pernyataan bahwa menulis untuk jurnal ilmiah CP itu prosedurnya cukup sulit. Pernyataan ini tidak benar, karena prosedur penulisan dapat dibaca pada bagian akhir dari jurnal tersebut dan ketentuannya sangat jelas. Ketentuan tersebut misalnya: karangan merupakan kajian suatu masalah pendidikan yang mengemukakan tentang ide pemecahan atau saran pemecahan, dan bersumber dari ide pemikiran atau literatus (LPPMP, 2012). Dari ketentuan tersebut maka jelas jika ada tulisan yang bukan masalah pendidikan tentu akan di tolak. Selain aturan-aturan yang mengatur tata cara penulisan, redaksi CP juga mempertimbangkan penulis dari luar UNY, hal ini dilakukan berujuan untuk menaikkan angka (skor) jika mengajukan aktreditasi. Itulah sebabnya para peneliti lokal harus bergantian dimuat dengan para penulis lain di luar UNY, selain harus menunggu giliran dengan teman sejawat di UNY.

Penelitian adalah suatu pencarian atas seseuatu (inquiry) secara sistematis dengan penekanan bahwa pencarian ini dilakukan terhadap masalah-masalah yang dapat dipecahkan. Untuk mencapai tujuan penelitian maka dipilihlah suatu metode pemecahan masalah, dan pandangan harus kritis dan prosedur harus sempurna ((Moh. Nasir, 2003: 13). Hasil akhir dari sebuah 
penelitian adalah tersajinya data-data dan kesimpulan. Penelitian yang baik tidak berhenti dalam sebuah bentuk laporan, melainkan harus dipublikasikan. Salah satu tempat publikasi yang relatif mudah adalah pada seminar-seminar, karena forum seminar bisa berlangsung kapan saja dan pada tingkat yang beragam dari tingkat lokal, nasional hingga skala internasional. Fakta menunjukkan bahwa sebagian besar dosen peneliti di UNY mmpublikasikan karyanya melalui seminar-seminar. Kondisi ini menggambarkan bahwa kesungguhan dosen peneliti di UNY untuk mempublikasikan karya penelitiannya sebenarnya cukup tinggi. Hal ini menunjukkan bahwa para dosen UNY telah bertanggung jawab atas funsi dosen sebagai tenaga psofesi, yang harus mengkomunikasikan ilmunya melalui publikasi ilmiah dalam bentuk seminar ilmiah. Sejalan dengan pemikiran Hamka Abdul Aziz (2012) yang menyatakan bahwa tenaga pendidik memiliki tugas dan tanggung jawab terhadap peserta didik dan masyarakat. Tugas dan tanggung jawab tersebut selain membaca, menulis, meneliti juga harus bisa berkomunikasi baik secara verbal maupun melalui berbagai media tulisan.

Kesulitan terbesar yang dialami para dosen peneliti di UNY adalah menulis pada jurnal ilmiah internasional. Hal ini mungkin lebih disebabkan oleh ketidak tahuan prosedur penulisan jurnal internasional dan komunikasi dengan pihak yang memiliki jurnal internasional. Inilah sebabnya ke depan LPPM bekerjasama dengan Wakil Rektor IV yang membidangi kerjasama antar lembaga harus sungguh-sungguh memecahkan prolem ini. Langkah awal yang mudah dijangkau adalah mengadakan workshop penulisan jurnal internasional, selain melakukan penjajakan kerjasama dengan perguruan tinggi luar negeri untuk urusan kegiatan ini.

Satu hal yang patut diberi penghargaan dari hasil penelitian dosen adalah terwujudnya kaya yang berupa buku ajar dari 107 peneliti ada 21 peneliti yang dapat menghasilkan buku ajar. Karya ini tidak hanya bermanfaat bagi peneneliti tapi juga bermanfaat bagi mahasiswa guna menunjang proses belajar mengajar. Seperti diketahui bersama bahwa di UNY buku-buku literatus karya dosen untuk menunjang perkuliahan mahasiswa masih tergolong kurang. Kebanyakan dosen mengajar cenderung menggunakan buku-buku karangan orang lain, sementara buku yang dibuat sendiri masih kurang. Jika dicermati pada Silabi dan RPP yang disusujn oleh dosen, maka akan ditemukan buku-buku rujukan yang digunakan oleh dosen yang bersangkutan kebanyakan buku-buku karangan orang lain dan tidak menyertakan buku wajib karya dosen yang bersangkutan. Karena itu penelitian dosen yang selanjutnya dapat menjadi buku ajar seharusnya menjadi perhatian bersama agar selalu terus-menerus didorong untuk lebih berkembang dan maju.

\section{SIMPULAN}

Berdasarkan temuan dan pembahasan, maka penelitian ini menyimpulkan sebagai berikut:

1. Jumlah penelitian yang telah dilakukan oleh dosen UNY selama kurun waktu 2007-2011 yang tercantum dalam sipenonline LPPM sebanyak 859 judul dengan rincian berasal dari fakultas: FBS: 150 judul; FE : 94 judul; FIK: 151 judul; FIP: 173 judul; FISE: 127 judul; FMIPA: 164 judul. Sumber dana penelitian tersebut berasal dari DP2M dengan skim penelitian Hibah Bersaing, fundamental, Rapid, Stranas, DIPA UNY baik unggulan universitas maupun DIPA masing-masing fakultas.

2. Profil pemanfaatan hasil penelitian dosen yang paling banyak berupa artikel yang diterbitkan dalam jurnal nasional yang belum terakreditasi sebanyak 35 judul, sebagai pemakalah dalam seminar nasional sebanyak 74 judul, seminar internasional sebanyak 21 judul, teknologi tepat guna sebanyak 24 judul, serta buku ajar sebanyak 21 judul.

3. Upaya yang perlu dilakukan LPPM dalam meningkatkan kualitas dan kuantitas penelitian yang banyak disarankan oleh 
responden adalah reviewer penelitian sesuai bidang ilmu; berkompeten, seminar instrumen dan hasil perlu ditingkatkan kualitasnya, jangan hanya formalitas, peluang penelitian perlu diperbanyak, serta tawaran penelitian tidak hanya melalui website.

4. Upaya yang perlu dilakukan LPPM dalam meningkatkan kualitas luaran/ pemanfaatan hasil-hasil penelitian yang banyak disarankan oleh para responden antara lain adalah agar LPPM mengadakan workshop penulisan artikel nasional terakreditasi/ internasional sebanyak 19 responden, mendorong terbitnya jurnal yang terakreditasi sebanyak 11 responden, serta memfasilitasi bantuan pengurusan pendaftaran HAKI sebanyak 7 responden.

Penelitian ini belum berhasil baik oleh karena responden yang mengirimkan kembali angket hanya 49\% dari total responden. Oleh karena itu ke depan perlu dilakukan cara-cara khusus, selain usaha memumbuhkan kesadaran dari para peneliti untuk melaporkan pemanfaatan hasil-hasil penelitiannya kepada LPPM.

\section{DAFTAR PUSTAKA}

DIKTI. (2012). Pedoman Penelitian. Jakarta. Dikti

Hamka Abdul Aziz. (2012). Karakter Guru Profesional, Jakarta: Al Mawardi Prima, RIP (Rencana Induk Penelitian) UNY Tahun 2012. LPPM UNY.

LPPMP UNY. (2012). Cakrawala Pendidikan, Majalah Ilmiah Nasional Kependidikan. Yogyakarta. UNY

Moh. Nasir. (2003). Metode Penelitian. Jakarta: Ghalia Indonesia

UNY. (2011). Laporan Tahunan Rektor Tahun 2011. Yogyakarta: UNY

www. Webometrics.com.

www.uny.ac.id. Website Universitas Negeri Yogyakarta. 